\title{
STATUS KETERPAJANAN HOUSEHOLD AIR POLLUTION (HAP) TERHADAP PANJANG BADAN BALITA KOTA PALEMBANG
}

\author{
Dwi Septiawati $^{1 *}$, Elvi Sunarsih ${ }^{2}$, Inoy Trisnaini $^{3}$,Ani Nidia Listianti ${ }^{4}$ \\ 1,2,3,4 Fakultas Kesehatan Masyarakat, Universitas Sriwijaya, Indralaya, Sumatera \\ Selatan. \\ Email: 1dwiseptiawati@unsri.ac.id, ${ }^{2}$ elvisunarsih@gmail.com, \\ ${ }^{3}$ inoytrissnaini@gmail.com, ${ }^{4}$ andialistianti@unsri.ac.id
}

\begin{abstract}
Abstrak
Sejumlah studi lainnya menemukan bukti yang mendukung hipotesis bahwa polusi udara dalam ruang dapat meningkatkan risiko gangguan pada pertumbuhan panjang badan balita. Tujuan penelitian untuk menganalisis hubungan status keterpajanan polusi udara dalam rumah terhadap pertumbuhan panjang badan balita Kota Palembang. Desain studi crossectional dengan 150 sampel. Teknik pengambilan sampel terpilih dilakukan dengan proportional random sampling. Data pertumbuhan fisik balita, pajanan udara dalam ruang, dan variabel lain yang diteliti merupakan data primer dari hasil wawancara langsung. Teknik analisa data secara univariat dan uji chi-square. Terbukti adanya hubungan antara HAP dengan pertumbuhan berat panjang balita yang tidak normal untuk indikator $\mathrm{PB} / \mathrm{U}$ ( $\mathrm{p}$ value: 0,002 ; PR 1.8; 95\%CI: 1.2-2.8). Faktor risiko lain yang juga berhubungan dengan pertumbuhan panjang badan balita yang tidak normal adalah pemberian ASI eksklusif (p value: 0,013; PR 1.5; 95\%CI: 1.1-2.2) dan pajanan asap rokok (p value: 0,048; PR 1.4; 95\%CI: 1.02-2.04). Pajanan polusi udara dalam ruang terbukti dapat mempengaruhi pertumbuhan panjang badan ideal pada balita
\end{abstract}

Kata kunci: Balita, household air pollution, pertumbuhan panjang badan

\footnotetext{
ABSTRACT

A case study that supports the hypothesis that aims to increase the level of exposure in the environment to increase the height of toddlers in the city of Palembang. Crossectional study design with 150 samples. The sampling technique is done by proportional random sampling. Data on toddlers' physical growth, air exposure in space, and other variables studied were primary data from direct interviews. Data analysis techniques are univariate and chi-square test. It was proven that there was a relationship between HAP and abnormal body height for TB/U indicators (p value: 0,002; PR 1.8; 95\%CI: 1.2-2.8). Other factors that are also related to abnormal height are exclusive breastfeeding (p value: 0,013; PR 1.5; 95\%CI: 1.1-2.2) and exposure to cigarette smoke ( $\mathrm{p}$ value: 0,048; PR 1.4; 95\%CI: 1.02-2.04). Exposure to indoor air pollution has been shown to influence the growth of ideal body height in toddlers.
} 
Keywords: Toddlers, household air pollution, height growth

\section{PENDAHULUAN}

Pencemaran udara dalam ruang (indoor air pollution) terutama rumah sangat berbahaya bagi kesehatan manusia, karena pada umumnya orang lebih banyak menghabiskan waktu untuk melakukan kegiatan di dalam rumah sehingga rumah menjadi sangat penting sebagai lingkungan mikro yang berkaitan dengan risiko dari pencemaran udara (Menkes RI, 2011). WHO melaporkan bahwa pada tahun 2012 ada sekitar 7 juta orang meninggal sebagai akibat dari pajanan polusi udara (WHO, 2014a). Setiap hari, binatang, kelembaban udara, produk rumah tangga dan faktor lingkungan lainnya, semua berkontribusi terhadap polusi udara dalam ruangan di gedunggedung publik dan rumah-rumah pribadi (Fitria dkk., 2008).

Merokok dan sistem pemanas yang rusak dapat memperkenalkan gas berbahaya ke udara dalam ruangan. Asap tembakau mengandung lebih dari 4.000 bahan kimia, termasuk 43 jenis yang telah diketahui menyebabkan kanker pada manusia dan hewan. Perokok dan nonperokok menghirup bahan kimia ini ketika orang merokok di dalam ruangan. Karbon monoksida - gas yang tidak berwarna dan tidak berbau yang mengganggu penyerapan oksigen dalam darah (Abusalah dkk., 2011; WHO, 2007). Meningkatnya polusi udara sejalan dengan peningkatan penyakit akut maupun kronik. Berdasarkan 10 penyebab kematian di dunia tahun 2011, penyakitpenyakit akibat pajanan polusi udara menjadi beberapa diantaranya, seperti penyakit infeksi saluran pernafasan bawah (3,2 juta kasus), COPD/ PPOK (3 juta kasus), Trachea broncus \& lung cancer (1,5 juta kasus), dan kelahiran prematur (1,2 juta kasus) (WHO, 2013). Selain penyakit tersebut di atas, kematian janin, Berat Bayi Lahir Rendah (BBLR), kematian bayi usia kurang dari satu minggu, otitis media dan stunting sering dijumpai pada lingkungan dengan kualitas udara dalam ruang yang tidak baik (Menkes RI, 2011).

Gangguan pertumbuhan masih menjadi masalah kesehatan di Indonesia. Data sementara Survei Kesehatan Nasional 2008 menunjukkan bahwa prevalensi perawakan pendek 37 persen pada balita yang diakibatkan selain oleh karena kurangnya pasokan gizi saat pertumbuhan, juga berat saat lahir di bawah standar 2,5 kilogram. Menurut hasil Susenas 2015, prevalensi anak balita yang mengalami gizi kurang (underweight) sebesar 28 persen, sedangkan (wasting) sebesar 15,5 persen (Tangga, 2015). Pembangunan kesehatan dalam periode tahun 2015-2019 difokuskan pada empat program prioritas yaitu penurunan angka kematian ibu dan bayi, penurunan prevalensi balita pendek (stunting), pengendalian penyakit menular dan pengendalian penyakit tidak menular (Kemenkes RI, 2016).

Pemantauan Status Gizi (PSG) 2015 menyebut 3,8\% Balita mengalami gizi buruk. Status Gizi Balita menurut Indeks Berat Badan per Usia (BB/U), didapatkan hasil: $79,7 \%$ gizi baik; $14,9 \%$ gizi kurang; $3,8 \%$ gizi buruk, dan 1,5\% gizi lebih. Status Gizi Balita Menurut Indeks Tinggi Badan per Usia (TB/U), didapatkan hasil: $71 \%$ normal dan $29,9 \%$ Balita pendek dan sangat pendek. Status Gizi Balita Menurut Indext Berat Badan per Tinggi Badan (BB/TB), didapatkan hasil,: $82,7 \%$ Normal, $8,2 \%$ kurus, $5,3 \%$ gemuk, dan 3,7\% sangat kurus. Dari $496 \mathrm{Kab} / \mathrm{kota}$ yang dianalisis, sebanyak $404 \mathrm{Kab} /$ Kota mempunyai permasalahan gizi yang bersifat Akut-Kronis; 20 Kab/Kota 
mempunyai permasalahan gizi yang bersifat Kronis; $63 \mathrm{Kab} /$ Kota mempunyai permasalahan gizi yang bersifat Akut; dan $9 \mathrm{Kab} /$ Kota yang tidak ditemukan masalah gizi. Kesembilan Kab/Kota tersebut, antara lain: 1) Kab. Ogan Komering Ulu, Sumatera Selatan; 2) Kota Pagar Alam, Sumatera Selatan; 3) Kab. Mukomuko, Bengkulu; 4) Kota Bengkulu, Bengkulu; 5) Kab. Belitung Timur, Bangka Belitung; 6) Kota Semarang, Jawa Tengah; 7) Kota Tabanan, Bali; 8) Kota Tomohon, Sulawesi Utara; dan 9) Kota Depok, Jawa Barat (Kemenkes RI, 2016).

Target penurunan prevalensi stunting (pendek dan sangat pendek) pada anak baduta (dibawah 2 tahun) adalah menjadi 28\% (RPJMN, 2015 - 2019) (Kemenkes RI, 2016). Diperkirakan terdapat 162 juta balita pendek pada tahun 2012, jika tren berlanjut tanpa upaya penurunan, diproyeksikan akan menjadi 127 juta pada tahun 2025. Sebanyak 56\% anak pendek hidup di Asia dan 36\% di Afrika (Kemenkes RI, 2016). Persentase status gizi balita pendek (pendek dan sangat pendek) di Indonesia Tahun 2013 adalah $37,2 \%$, jika dibandingkan tahun $2010(35,6 \%)$ dan tahun 2007 (36,8\%) tidak menunjukkan penurunan/ perbaikan yang signifikan (Litbangkes, 2013). Dibandingkan beberapa negara tetangga, prevalensi balita pendek di Indonesia juga tertinggi dibandingkan Myanmar (35\%), Vietnam (23\%), Malaysia (17\%), Thailand. (16\%) dan Singapura (4\%) (UNSD, 2014). Global Nutrition Report tahun 2014 menunjukkan Indonesia termasuk dalam 17 negara, di antara 117 negara, yang mempunyai tiga masalah gizi yaitu stunting, wasting dan overweight pada balita (Kemenkes RI, 2016). .

Persentase status gizi balita (usia 059 bulan) di Provinsi Sumatera Selatan tahun 2015 adalah sebesar $1.7 \%$ gizi buruk, 12.4 gizi kurang, $84.5 \%$ gizi baik, $1.4 \%$ gizi kurang, serta $14.1 \%$ gizi buruk+kurang. Kota Palembang sendiri memiliki persentase status gizi balita yaitu $2 \%$ gizi buruk, $10.1 \%$ gizi kurang, $86.6 \%$ gizi baik, $1.4 \%$ gizi lebih, serta12\% gizi buruk+kurang (Kemenkes RI, 2016). Data ini menjelaskan bahwa permasalahan status gizi balita atau pertumbuhan fisik balita masih menjadi masalah di provinsi Sumatera Selatan secara umum dan Kota Palembang secara khusus.

Penggunaan bahan bakar biomassa untuk memasak dan keberadaan asap rokok salah satu sumber emisi polutan udara yang menyebabkan tingkat polusi udara yang tinggi di dalam ruangan. Paparan asap biofuel telah dikaitkan dengan penurunan berat badan lahir dan infeksi saluran pernapasan akut (ISPA) dan kematian pada anak usia dini, namun sedikit yang diketahui tentang pengaruhnya terhadap status gizi dan pertumbuhan fisik anak-anak. Sejumlah studi lainnya menemukan bukti yang mendukung hipotesis bahwa polusi udara dalam ruang dapat meningkatkan risiko gangguan pada pertumbuhan fisik balita (Control dan Prevention, 2011; Dadras dan Chapman, 2017; Goyal dan Canning, 2017; McConnell dkk., 2015; Mishra dan Retherford, 2006; Muraro dkk., 2014; Septiawati dkk., 2017). Korelasi ini terjadi karena sanitasi yang buruk dapat meningkatkan kejadian penyakit infeksi yang dapat membuat energi untuk pertumbuhan teralihkan kepada perlawanan tubuh menghadapi infeksi, gizi sulit diserap oleh tubuh dan terhambatnya pertumbuhan. Tujuan penelitian ini adalah menganalisis hubungan status keterpajanan polusi udara dalam rumah terhadap panjang badan balita Kota Palembang

\section{METODE PENELITIAN}

Penelitian ini dilakukan di 16 kecamatan di Kota Palembang. Pengumpulan data hingga analisis dilakukan pada Bulan Maret 2018 hingga 
September 2018. Penelitian ini menggunakan metode kuantitatif dengan jenis rancangan penelitian Crossectional Study. Disain studi crossectional adalah penelitian yang membandingkan kelompok balita yang memiliki status keterpajanan tinggi terhadap polusi udara dalam ruang dibandingkan dengan kelompok balita yang tidak memiliki ciri tersebut sebagai pembanding. Perbandingan dilakukan dengan membandingkan kasus (effects) dari variabel yang diduga menjadi penyebab terjadinya kasus-kasus yang diteliti. Penelitian crossectional merupakan penelitian yang menggunakan pendekatan satu waktu (one time approach) dalam pengambilan data penyebab dan akibat.

Populasi studi dalam penelitian ini adalah seluruh jumlah balita di Kota Palembang, Sumatera Selatan Tahun 2017. Sampel penelitian ini adalah sebagian dari balita yang diwakili oleh rumah tangga balita sebagai unit populasi dengan anggota rumah tangga dewasa (usia $\geq 17$ tahun) sebagai responden penelitian. Dikarenakan penelitian ini mengumpulkan data primer mengenai karakteristik, variabel pencemaran udara, serta faktor risiko pertumbuhan fisik balita maka harus diketahui terlebih dahulu besar proporsi dari variabel status pertumbuhan fisik balita dari hasil penelitian sebelumnya untuk kemudian dihitung besar sampel minimum.

$\begin{array}{cll}\begin{array}{c}\text { Proses } \\ \text { minimum }\end{array} & \text { menghitung } & \text { sampel } \\ \text { dilakukan } & \text { dengan }\end{array}$
memperhitungkan nilai $\alpha, \quad 1-\beta, \quad \mathrm{P} 1$ (proporsi balita dengan panjang badan tidak normal pada kelompok terpajan tinggi polusi udara dalam ruang), P2 (proporsi balita dengan panjang badan tidak normal pada kelompok terpajan rendah polusi udara dalam ruang). Bila dalam studi literatur tidak ditemukan nilai P1 dan P2 maka nilai P2 dapat menggunakan nilai proporsi pajanan di populasi dan P1 dapat dicari dengan menggunakan rumus (Lemeshow, 1990). Menggunakan derajat kepercayaan sebesar 95\% $(\alpha=0,05)$, kekuatan uji 90\% $(\beta=0,10)$, nilai P1 (proporsi kasus pada kelompok terpajan $)=43,1 \%$ (Dadras dan Chapman, 2017) dan nilai P2 (proporsi kasus pada kelompok tidak terpajan)= 61\% (Mishra dan Retherford, 2006) maka perhitungan jumlah sampel minimal yang akan diteliti dapat dilakukan dengan menggunakan persamaan (Lemeshow, 1990). Dari persamaan tersebut didapatkan hasil sampel minimal sebesar 132 rumah tangga balita. Selanjutnya, drop out dicegah dengan melakukan penambahan sampel sebanyak $10 \%$ sehingga $132+10 \%$ dari $132=145$ sehingga sampel penelitian yang dibutuhkan berjumlah 145 rumah tangga balita. Selanjutnya sampel dicukupkan hingga 150 rumah tangga balita. Rumah tangga balita yang akan dijadikan sampel dipilih menggunakan metode pengambilan sampel secara justified sampling dengan tehnik cluster sampling untuk penentuan lokasi studi setelah sebelumnya dilakukan proses seleksi berdasarkan kriteria inklusi. Penentuan jumlah unit sampel pada tiap cluster akan dipilih secara proporsional sampling menggunakan persamaan proporsional sampling dan pemilihan unit sampel yang akan didatangi untuk digali informasi dipilih dengan cara justified sampling.

Data diolah dalam bentuk tabel. Analisis data yang dilakukan bersifat kuantitatif dan deskriptif. Penelitian ini melakukan analisis data univariat untuk mengetahui distribusi frekuesnsi dari:

a. Karakteristik responden

b. Gambaran pertumbuhan fisik balita pada populasi studi

c. Gambaran pajanan polusi udara dalam ruang

d. Faktor- faktor risiko lain seperti faktor internal balita (umur, riwayat menyusu, riwayat penyakit infeksi) dan faktor eksternal balita (genetika, status 
anemia ibu saat hamil, jenis bahan bakar masak yg digunakan, status second hand smoker, kondisi fisik rumah).

Analisis bivariat bertujuan untuk melihat hubungan antara variabel independen terhadap variabel dependen. Pada penelitian ini, analisis bivariat digunakan untuk melihat hubungan antara variabel status pajanan polusi udara dalam ruang terhadap pertumbuhan fisik balita. Selain itu, faktor risiko lainnya seperti faktor internal balita (umur, riwayat menyusu, riwayat penyakit infeksi) dan faktor eksternal balita (genetika, status anemia ibu saat hamil, jenis bahan bakar masak yg digunakan, status second hand smoker, kondisi fisik rumah) juga dilakukan analisis bivariat terhadap pertumbuhan fisik balita.

Uji statistik yang digunakan dalam penelitian ini adalah chi-square dengan tingkat kemaknaan $95 \%(\alpha=0,05)$. Adapun alasan menggunakan chi-square karena data yang akan diolah merupakan data kategori atau diskrit yaitu data panjang badan balita (normal dan tidak normal) serta data status pajanan polusi udara dalam ruang (terpajan tinggi dan terpajan rendah). Adapun langkah dalam melakukan uji hubungan menggunakan chi square adalah sebagai berikut:

1) Menggambarkan deskripsi masingmasing sel dari variabel yang akan dihubungkan untuk melihat nilai observed dan expected

2) Melihat ada atau tidaknya nilai expected yang kurang dari 5 sebanyak lebih dari $25 \%$

3) Menentukan jenis nilai $p$ yang dipakai yaitu Continuity Correction bila tidak ada nilai expected yang kurang dari 5 sebanyak lebih dari $25 \%$ dan Fisher
Exact bila ada nilai expected yang kurang dari 5 sebanyak lebih dari $25 \%$

4) Membandingkan nilai signifikansinya (nilai $p$ ) dengan nilai $\alpha(0,05)$

5) Membuat kesimpulan hasil uji yaitu apabila nilai $p$ yang didapat lebih kecil dari nilai $\alpha(0,05)$ maka hipotesis null (H0) ditolak yang artinya variabel independen tersebut memiliki hubungan dengan variabel dependen.

6) Menyajikan data dalam bentuk tabel dan narasi

Untuk mengetahui derajat hubungan antara pajanan polusi udara dalam ruang terhadap panjang balita dilihat melalui nilai Prevalens Ratio (PR). Prevalensi ratio adalah perbandingan nilai prevalensi panjang badan tidak normal pada kelompok balita yang terpajan tinggi polusi udara dalam ruang dibandingkan dengan nilai prevalensi panjang badan tidak normal pada kelompok pembanding. Nilai PR:

- Sama dengan $1 \rightarrow$ tidak ada hubungan antara pajanan polusi udara dalam ruang pada terhadap panjang badan balita.

- $<1 \rightarrow$ pajanan polusi udara dalam ruang merupakan faktor risiko terhadap panjang badan balita yang tidak normal.

- $>1 \rightarrow$ pajanan polusi udara dalam ruang merupakan faktor proteksi terhadap panjang badan balita yang tidak normal.

\section{HASIL DAN PEMBAHASAN}

\section{Gambaran Panjang Badan Balita}

Gambaran terhadap panjang badan atau tinggi badan, umur balita, dan jenis kelamin dijelaskan dalam Tabel 1 dan Tabel 2. 
Tabel 1. Gambaran Distribusi Frekuensi Panjang Badan, Berat Badan dan Usia Balita

\begin{tabular}{llllll}
\hline & n & Min & Max & Mean & Std. Dev \\
\hline Panjang Balita (cm) & 150 & 41 & 120 & 79.86 & 19.189 \\
Usia Balita (bulan) & 150 & 0 & 60 & 27.41 & 16.760 \\
\hline
\end{tabular}

Tabel 2. Gambaran Distribusi Frekuensi Jenis Kelamin Balita

\begin{tabular}{ccc}
\hline Jenis Kelamin & n & \% \\
\hline Laki-Laki & 72 & 48 \\
Perempuan & 78 & 52 \\
Total & $\mathbf{1 5 0}$ & $\mathbf{1 0 0}$ \\
\hline
\end{tabular}

Dari Tabel 1 dan Tabel 2 diketahui bahwa dalam sampel penelitian ini, ratarata balita yang diamati berumur 27 bulan dengan rata-rata panjang badan atau tinggi badan $79 \mathrm{~cm}$ dengan distribusi sebaran jenis kelamin yang hampir sama banyak dimana balita dengan jenis kelamin lakilaki sebanyak $48 \%$ dan $52 \%$ berjenis kelamin perempuan. Selanjutnya, untuk melihat dan menentukan status pertumbuhan fisik Balita dilakukan dengan cara membandingkan panjang badan balita terhadap umur yang tergambar pada Tabel 3.

Tabel 3 Gambaran Distribusi Frekuensi TB/Umur

\begin{tabular}{lcc}
\hline Variabel & N & \% \\
\hline Panjang Badan/ Umur & & \\
1. Tidak Normal & 73 & 48.7 \\
2. Normal & 77 & 51.3 \\
\hline Total & $\mathbf{1 5 0}$ & $\mathbf{1 0 0}$ \\
\hline
\end{tabular}

Berdasarkan Tabel 3 diketahui bahwa sebagian besar balita dalam penelitian ini memiliki panjang badan yang sesuai dengan umurnya $(51,3 \%)$.

\section{Pajanan Polusi Udara di Dalam Rumah} Distribusi frekuensi mengenai pajanan polusi udara di dalam rumah terbagi menjadi 2 kategori yaitu pajanan tinggi dan pajanan rendah. Penentuan status keterpajanan dilakukan dengan mempertimbangkan keberadaan sumber polusi udara dalam rumah (household air pollution) (Tabel 4).

Tabel 4. Gambaran Distribusi Frekuensi Pajanan Polusi Udara di Dalam Rumah

\begin{tabular}{lcc}
\hline Status Pajanan & N & \% \\
\hline 1. Pajanan Tinggi & 93 & 62 \\
2. Pajanan Rendah & 57 & 38 \\
\hline Total & $\mathbf{1 5 0}$ & $\mathbf{1 0 0}$ \\
\hline
\end{tabular}

Diketahui bahwa sebagian besar balita terpajan tinggi oleh polusi udara di dalam rumah (62\%). Polutan yang diindikasikan menjadi sumber polusi udara di dalam rumah balita dijelaskan pada Tabel 5.

\section{Sumber Polusi Udara di Dalam Rumah}

Beberapa faktor atau variabel diduga menjadi sumber dari polusi udara dalam rumah balita. Distribusi frekuensi dari sumber polusi udara dalam rumah dijelaskan pada Tabel 5.

Dari Tabel 5 diketahui bahwa sebagian besar polusi udara di dalam rumah balita bersumber dari keberadaan anggota rumah tangga yang merokok $(63.3 \%)$, penggunaan obat nyamuk bakar $(55,3 \%)$, dan letak dapur di dalam rumah $(98 \%)$ 
Tabel 5. Gambaran Distribusi Frekuensi Sumber Polusi Udara di Dalam Rumah

\begin{tabular}{lcc}
\hline Variabel & n & \% \\
\hline Jenis Bahan Bakar Memasak & & \\
1. Kayu Bakar & 1 & 0.7 \\
2. Minyak Lampu & 2 & 1.3 \\
3. Gas & 147 & 98 \\
\hline Anggota Rumah Tangga Merokok & & \\
1. Ada & 95 & 63.3 \\
2. Tidak Ada & 55 & 36.7 \\
\hline Penggunaan Obat Nyamuk Bakar & & \\
1. Ya & 83 & 55.3 \\
2. Tidak Pernah & 67 & 44.7 \\
\hline Penggunaan Aerosol & & \\
1. Ya & 74 & 49.3 \\
2. Tidak Pernah & 76 & 50.7 \\
\hline Letak Dapur & & \\
1. Dalam Rumah & 147 & 98 \\
2. Luar Rumah & 3 & 2 \\
\hline Kepemilikan Plavon & & \\
1. Ada & 83 & 55.3 \\
2. Tidak Ada & 67 & 44.7 \\
\hline Jenis Dinding & & \\
1. Berisiko & 66 & 44 \\
2. Tidak Berisiko & 84 & 56 \\
\hline Jenis Lantai & & \\
1. Berisiko & 32 & 21.3 \\
2. Tidak Berisiko & 118 & 78.7 \\
\hline Total & $\mathbf{1 5 0}$ & $\mathbf{1 0 0}$ \\
\hline
\end{tabular}

Tabel 6. Tabulasi Silang Antara Pajanan Polusi Udara di Dalam Rumah terhadap Panjang Badan Balita (Panjang Badan per Umur)

\begin{tabular}{ccccc}
\hline & Tidak Normal & Normal & p value & $\begin{array}{c}\text { 95\% CI } \\
\text { (Lower-Upper) }\end{array}$ \\
\cline { 1 - 4 } Pajanan Tinggi & $55(59.1 \%)$ & $38(40.9 \%)$ & 0.002 & 1.873 \\
Pajanan Rendah & $18(31.6 \%)$ & $39(68.4 \%)$ & & $(1.233-2.844)$ \\
\hline
\end{tabular}

Hubungan Polusi Udara dalam Rumah Terhadap Panjang Badan Balita

Terdapat hubungan antara status pajanan polusi udara dalam rumah terhadap pertumbuhan fisik balita yang dinilai dari panjang badan dibandingkan dengan umur. Hal ini diketahui dari nilai $\mathrm{p}$ (0.002) yang lebih kecil dari nilai alpha (0.05). Pada penelitian ini diketahui, balita dengan status pajanan tinggi polusi udara dalam rumah berisiko 1.8 kali mengalami pertumbuhan fisik yang tidak normal. Pada populasi umum, peneliti memiliki kepercayaan $95 \%$ bahwa balita dengan status pajanan tinggi polusi udara dalam rumah berisiko 1.2 kali hingga 2.8 kali untuk mengalami panjang badan $(\mathrm{PB} / \mathrm{U})$ yang tidak normal dibandingkan dengan balita dengan status pajanan rendah polusi udara dalam rumah.

\section{Faktor Risiko Lain yang Mempengaruhi Pertumbuhan Fisik Balita}

Selain polusi udara di dalam rumah, terdapat faktor risiko lain yang diduga memiliki hubungan dengan panjang badan balita. Hubungan tersebut terlihat pada Tabel 7. Berdasarkan Tabel 7 diketahui bahwa Asi Eksklusif berhubungan dengan 
panjang badan balita $(\mathrm{PB} / \mathrm{U})$. Hal ini diketahui dari nilai $\mathrm{p}(0.013)$ yang lebih kecil dari nilai alpha (0.05). Pada penelitian ini diketahui, balita yang tidak diberikan ASI secara eksklusif berisiko 1.5 kali mengalami panjang badan yang tidak normal. Pada populasi umum, peneliti memiliki kepercayaan $95 \%$ bahwa balita yang tidak diberikan ASI secara eksklusif berisiko 1.1 kali hingga 2.2 kali untuk mengalami panjang badan $(\mathrm{PB} / \mathrm{U})$ yang tidak normal dibandingkan dengan balita yang diberikan ASI Eksklusif.

Selain itu, terdapat hubungan antara second hand smoke dengan pertumbuhan fisik balita yang dinilai dari panjang badan dibandingkan dengan umur. Hal ini diketahui dari nilai $\mathrm{p}(0.048)$ yang lebih kecil dari nilai alpha (0.05). Selain itu, pada penelitian ini didapatkan nilai risiko dari balita yang terpajan asap rokok di dalam rumah terhadap panjang badan yang tidak normal yaitu sebesar 1.4 kali. Pada populasi umum, peneliti memiliki kepercayaan $95 \%$ bahwa balita yang terpajan asap rokok di dalam rumah berisiko 1 kali hingga 2 kali untuk mengalami panjang badan $(\mathrm{PB} / \mathrm{U})$ yang tidak normal dibandingkan dengan balita yang tidak terpajan asap rokok di dalam rumah.

Faktor risiko lainnya seperti IMT ayah, IMT ibu, penyakit penyerta pada balita, status anemia ibu saat hamil, serta jenis bahan bakar memasak terbukti tidak memiliki hubungan dengan pertumbuhan fisik balita yaitu panjang badan (PB/U) dikarenakan nilai $\mathrm{p}$ yang lebih besar dibandingkan dengan nilai alpha (0.05).

Tabel 7. Tabulasi Silang Antara Faktor Lainnya terhadap Pertumbuhan Fisik Balita (Panjang Badan per Umur)

\begin{tabular}{|c|c|c|c|c|}
\hline & Tidak Normal & Normal & p value & $\begin{array}{c}95 \% \text { CI } \\
\text { (Lower-Upper) }\end{array}$ \\
\hline \multicolumn{5}{|l|}{ IMT Ayah } \\
\hline 1. Berisiko & $43(49.4 \%)$ & $44(50.6 \%)$ & 0.958 & 1.038 \\
\hline 2. Tidak Berisiko & $30(57.6 \%)$ & $33(52.4 \%)$ & & $(0.742-1.451)$ \\
\hline \multicolumn{5}{|l|}{ IMT Ibu } \\
\hline 1. Berisiko & $43(47.3 \%)$ & $48(52.7 \%)$ & 0.792 & 0.929 \\
\hline 2. Tidak Berisiko & $30(50.8 \%)$ & $29(49.2 \%)$ & & $(0.667-1.295)$ \\
\hline \multicolumn{5}{|l|}{ Asi Eksklusif } \\
\hline 1. Tidak & $47(58.8 \%)$ & $33(41.2 \%)$ & 0.013 & 1.582 \\
\hline 2. Ya & $26(37.1 \%)$ & $44(62.9 \%)$ & & $(1.108-2.258)$ \\
\hline \multicolumn{5}{|l|}{ Penyakit Penyerta } \\
\hline 1. Tidak Ada & $32(50 \%)$ & $32(50 \%)$ & 0.907 & 1.049 \\
\hline 2. Ada & $41(47.7 \%)$ & $45(52.3 \%)$ & & $(0.754-1.459)$ \\
\hline \multicolumn{5}{|l|}{ Anemia Saat Hamil } \\
\hline 1. Ya & $18(56.2 \%)$ & $14(43.8 \%)$ & 0.352 & - \\
\hline 2. Tidak & $54(46.2 \%)$ & $63(53.8 \%)$ & & \\
\hline 3. Tidak Tau/ Lupa & $1(100 \%)$ & $0(0 \%)$ & & \\
\hline \multicolumn{5}{|l|}{ Second Hand Smoke } \\
\hline 1. Ada & $45(57 \%)$ & $34(43 \%)$ & 0.048 & 1.444 \\
\hline 2. Tidak Ada & $28(39.4 \%)$ & $43(60.6 \%)$ & & $(1.022-2.042)$ \\
\hline \multicolumn{5}{|c|}{ Bahan Bakar Masak } \\
\hline 1. Kayu Bakar & $0(0 \%)$ & $1(100 \%)$ & 0.216 & - \\
\hline 2. Minyak Lampu & $2(100 \%)$ & $0(0 \%)$ & & \\
\hline 3. Gas & $71(46.9 \%)$ & $76(51.7 \%)$ & & \\
\hline
\end{tabular}


Masa balita merupakan periode penting dalam proses tumbuh kembang manusia. Perkembangan dan pertumbuhan di masa itu menjadi penentu keberhasilan pertumbuhan dan perkembangan anak di periode selanjutnya. Masa tumbuh kembang di usia ini merupakan masa yang berlangsung cepat dan tidak akan pernah terulang, karena itu sering disebut golden age atau masa keemasan (Kementerian Kesehatan RI, 2011).

Anak yang sehat akan menunjukkan pertumbuhan yang optimal, apabila diberikan lingkungan bio-fisikopsikososial yang adekuat. Faktor penentu kualitas pertumbuhan anak adalah faktor intrinsik (genetik, kelainan kongenital, dan hormonal) dan faktor ekstrinsik (kualitas dan kuantitas nutrisi, penyakit kronik, serta gangguan emosional). Deteksi pertumbuhan perlu dilakukan sendini mungkin sejak masih di dalam kandungan. Status gizi balita atau dalam konteks ini adalah pertumbuhan fisik balita dinilai menurut 3 indeks, yaitu Berat Badan Menurut Umur (BB/U), Tinggi Badan Menurut Umur (TB/U), Berat Badan Menurut Tinggi Badan (BB/TB) (Departemen Kesehatan, 2000).

Berdasarkan hasil penelitian diketahui bahwa rata-rata balita yang diamati berumur 27 bulan dengan rata-rata panjang badan atau tinggi badan $79 \mathrm{~cm}$ dan berat badan 11000 gram dan sebagian besar balita dalam penelitian ini memiliki berat badan yang sesuai dengan umurnya (52\%), dan memiliki panjang badan yang sesuai dengan umurnya (51,3\%). Pertumbuhan merupakan komponen penting dalam menilai status nutrisi dan dapat digunakan sebagai indikator dari kesehatan/ kesejahteraan individu maupun populasinya.

Ada banyak variabel yang menjadi faktor risiko dari terhambatnya atau terganggunya pertumbuhan fisik seorang balita seperti polusi udara, faktor genetik, riwayat anemia ibu saat hamil, penyakit peyerta pada balita, keterpajanan asap rokok, penggunaan bahan bakar memasak dan lainnya.

Pencemaran udara dalam ruang (Indoor air pollution) terutama rumah sangat berbahaya bagi kesehatan manusia karena pada umumnya orang lebih banyak menghabiskan waktu untuk melakukan kegiatan didalam rumah sehingga rumah menjadi sangat penting sebagai lingkungan mikro yang berkaitan dengan risiko dari pencemaran udara. Kualitas udara yang buruk dalam ruang dapat menimbulkan gangguan kesehatan. Setiap pembangunan perumahan harus memenuhi persyaratan kualitas udara dalam ruang rumah (Menkes RI, 2011). Peningkatan kadar bahan polutan di dalam ruangan selain dapat berasal dari penetrasi polutan dari luar ruangan, dapat pula berasal dari sumber polutan di dalam ruangan, seperti asap rokok, asap yang berasal dari dapur atau pemakaian obat anti nyamuk.

Pada penelitian ini diketahui bahwa sebagian besar balita terpajan tinggi oleh polusi udara di dalam rumah $(62 \%)$ dan sebagian besar polusi udara di dalam rumah balita bersumber dari keberadaan anggota rumah tangga yang merokok (63.3\%), penggunaan obat nyamuk bakar $(55,3 \%)$, dan letak dapur di dalam rumah (98\%).

Hasil uji hubungan membuktikan terdapat hubungan antara status pajanan polusi udara dalam rumah terhadap pertumbuhan fisik balita yang dinilai dari panjang badan dibandingkan dengan umur. Selain itu, pada penelitian ini didapatkan nilai risiko dari balita dengan status pajanan tinggi polusi udara dalam rumah terhadap panjang badan balita yang tidak normal yaitu 1.8 kali.

Sebuah studi menunjukkan bahwa polusi udara dalam ruangan mengurangi pengiriman $\mathrm{O}_{2}$ ke plasenta dan serapan janin yang menghasilkan berat dan berat lahir rendah. Dengan hasil ini dapat 
disimpulkan bahwa tidak ada ventilasi di dapur berisiko untuk menyebabkan stunting terutama baik bagi rumah tangga yang menggunakan bahan bakar gas atau biogas. Namun hasil ini harus ditafsirkan dengan hati-hati karena penelitian tersebut belum mengidentifikasi tingkat paparan anak terhadap polusi udara dalam ruangan (Bruce dkk., 2015; Dadras dan Chapman, 2017; Yisak dkk., 2015).

Faktor lainnya yang juga terbukti berhubungan dengan panjang badan balita $(\mathrm{PB} / \mathrm{U})$ adalah asi eksklusif dan pajanan asap rokok di dalam rumah. Pemberian ASI eksklusif merupakan salah satu faktor yang terbukti mempengaruhi pertumbuhan balita. Rendahnya pemberian ASI eksklusif menjadi salah satu pemicu terjadinya stunting pada anak balita yang disebabkan oleh kejadian masa lalu dan akan berdampak terhadap masa depan anak balita, sebaliknya pemberian ASI yang baik oleh ibu akan membantu menjaga keseimbangan gizi anak sehingga tercapai pertumbuhan anak yang normal. Anak balita yang diberikan ASI eksklusif dan MP-ASI sesuai dengan dengan kebutuhannya dapat mengurangi resiko tejadinya stunting. Hal ini karena pada usia 0-6 bulan ibu balita yang memberikan ASI eksklusif yang dapat membentuk imunitas atau kekebalan tubuh anak balita sehingga dapat terhindar dari penyakit infeksi (Aridiyah dkk., 2015).

Asap rokok tidak hanya berbahaya bagi diri perokok saja, melainkan juga mengandung resiko besar bagi orangorang di sekitarnya. Orang yang terekspos asap rokok biasa disebut sebagai perokok pasif. Perokok pasif adalah orang-orang yang menghirup asap yang dihembuskan oleh orang lain yang mengisap rokok, cerutu, dan pipa. Resiko asap rokok terhadap anak-anak lebih besar karena mereka sedang berada dalam masa pertumbuhan. Jika Anda merokok di dekat anak - anak atau jika mereka terekspos pada asap rokok di tempat lain, mungkin saja ada bahaya yang lebih mengancam daripada yang dikira. Begitu juga pada anak - anak yang orang tuanya merokok hanya di luar rumah, akan tetap terekspos pada bahan kimia dari rokok melalui udara yang mereka hirup (Dadras dan Chapman, 2017). Proporsi anak-anak yang mengalami stunting lebih tinggi di antara anak-anak yang tinggal di rumah tangga dimana setidaknya terdapat satu anggota rumah tangganya yang merokok, dan risiko ini meningkat seiring bertambahnya usia dan urutan kelahiran anak (Mishra dan Retherford, 2006; Muraro dkk., 2014).

\section{KESIMPULAN}

Polusi udara dalam ruang merupakan salah satu faktor eksternal balita yang berhubungan dengan gangguan pertumbuhan panjang badan balita. Selain itu faktor pemberian asi eksklusif dan pajanan terhadap asap rokok juga terbukti secara signifikan berhubungan dengan pertumbuhan panjang badan balita.

\section{UCAPAN TERIMA KASIH}

Ucapan terimakasih diberikan pada pemberi dana penelitian yaitu LPPM Universitas Sriwijaya serta pihak-pihak yang berjasa dalam membantu pelaksanaan penelitian.

\section{DAFTAR PUSTAKA}

Abusalah, A., Gavana, M., Haidich, A.-B., Smyrnakis, E., Papadakis, N., Papanikolaou, A., \& Benos, A. (2011). Low Birth Weight and Prenatal Exposure to Indoor Pollution from Tobacco Smoke and Wood Fuel Smoke: A Matched Case- 
Control Study in Gaza Strip. Maternal Children Health Journal, 16, 17181727. doi: DOI 10.1007/s10995-011-0851-4

Aridiyah, F. O., Rohmawati, N., \& Ririanty, M. (2015). Faktor-faktor yang Mempengaruhi Kejadian Stunting pada Anak Balita di Wilayah Pedesaan dan Perkotaan (The Factors Affecting Stunting on Toddlers in Rural and Urban Areas). Pustaka Kesehatan, 3(1), 163-170.

Bruce, N., Pope, D., Rehfuess, E., Balakrishnan, K., Adair-Rohani, H., \& Dora, C. (2015). WHO indoor air quality guidelines on household fuel combustion: Strategy implications of new evidence on interventions and exposure-risk functions. Atmospheric Environment, 106, 451-457.

Control, C. f. D. \& Prevention (2011). CDC grand rounds: childhood obesity in the United States. MMWR. Morbidity and mortality weekly report, 60(2), 42.

Dadras, O., \& Chapman, R. S. (2017). Biomass Fuel Smoke and Stunting in Early Childhood: Finding from a National Survey Nepal. Journal of Health Research, 31, s7-s15.

Departemen Kesehatan RI. (2000). Pedoman deteksi dini tumbuh kembang balita. Direktorat Kesehatan Keluarga, Direktorat Jenderal Kesehatan Masyarakat, Departemen Kesehatan, Jakarta.

Elwood, J. M. (2007). Critical Appraisal of Epidemiological Studies and Clinical Trials. Oxford University Press, New York.

Fitria, L., Wulandari, R. A., Hermawati, E., \& Susanna, D. (2008). Kualitas Udara dalam Ruang Perpustakaan Universitas "x" Ditinjau Dari Kualitas Biologi, Fisik, dan Kimiawi. MAKARA, KESEHATAN, 12( 2 ), 76-82.

Goyal, N. \& Canning, D. (2017). Exposure to Ambient Fine Particulate Air Pollution in Utero as a Risk Factor for Child Stunting in Bangladesh. International journal of environmental research and public health, 15(1), 22.

Grantham, M., S. M., Fernald, L. C., Kagawa, R., \& Walker, S. (2014). Effects of integrated child development and nutrition interventions on child development and nutritional status. Annals of the New York Academy of Sciences, 1308(1), 11-32.

Kementerian Kesehatan, RI. (2011). Standar antropometri penilaian status gizi anak. Direktorat Bina Gizi, Jakarta.

Kementrian Kesehatan, RI. Pusat Data dan Informasi. (2016). Situasi Balita Pendek. Kementerian Kesehatan Republik Indonesia.

Kusnoputranto, H. (2000). Kesehatan Lingkungan. FKM UI, Depok.

Lemeshow. (1990). Adequacy of Sample Size in Health Studies (D. Pramono, Trans.). John Wiley \& Sons, Genewa.

Litbangkes. (2013). Riset Nasional Kesehatan Dasar (Riskesdas) 2013. Kementerian Kesehatan Republik Indonesia, Jakarta.

McConnell, R., Shen, E., Gilliland, F. D., Jerrett, M., Wolch, J., Chang, C.-C., Berhane, K. (2015). A longitudinal cohort study of body mass index and childhood exposure to secondhand tobacco smoke and air pollution: the Southern California Children's Health Study. Environmental Health Perspectives, $123(4), 360$.

Menkes RI. (2011). Peraturan Menteri Kesehatan Republik Indonesia Nomor 1077/MENKES/PER/V/2011 TENTANG PEDOMAN PENYEHATAN UDARA DALAM RUANG RUMAH. Jakarta: Retrieved from 
http://www.tungkuindonesia.org/images/downloads/Peraturan_Menteri_Keseh atan_No.1077.pdf.

Mey Liswati, E., Widyaningsih, E. N., ST, S., Hapsari, I. B., \& SiT, S. (2016). Hubungan Karakteristik Ibu Dengan Status Gizi Anak Balita Yang Memiliki Jamkesmas Di Desa Tegal Giri Kecamatan Nogosari Kabupaten Boyolali. Universitas Muhammadiyah Surakarta.

Mishra, V. \& Retherford, R. D. (2006). Does biofuel smoke contribute to anaemia and stunting in early childhood? International Journal of Epidemiology, 36(1), 117-129.

Muaris, H. (2006). Sarapan sehat untuk anak balita: Gramedia Pustaka Utama.

Muraro, A. P., Gonçalves-Silva, R. M. V., Moreira, N. F., Ferreira, M. G., NunesFreitas, A. L., Abreu-Villaça, Y., \& Sichieri, R. (2014). Effect of tobacco smoke exposure during pregnancy and preschool age on growth from birth to adolescence: a cohort study. BMC pediatrics, 14(1), 99.

Novitasari, A., Waluyo, H., \& Anfasa, A. Y. (2014). Hubungan Karakteristik Ibu terhadap Status Gizi Balita di Kabupaten Kendal. Jurnal Kedokteran Muhammadiyah, 3(1).

RI, K. K. (2016). Buku Saku Pemantauan Status Gizi dan Indikator Kinerja Gizi Tahun 2015: Jakarta.

Septiawati, D., Fitria, L., Wulandari, R. A., Zahra, Z., \& Listianti, A. N. (2017). Pengaruh Pajanan Nitrogen Dioksida (N02) terhadap Berat Badan Lahir Rendah (Bblr), di Kota Palembang, Provinsi Sumatera Selatan. Jurnal Ekologi Kesehatan, 16(1), 36-45.

Siagian, R. L., Sudaryati, E., \& Siagian, A. (2016). Gambaran Perilaku Ibu dalam Pemanfaatan KMS dan Status Gizi Baduta di Wilayah Kerja Puskesmas Lawe Perbunga Kecamatan Babul Makmur Kabupaten Aceh Tenggara Tahun 2015. Gizi, Kesehatan Reproduksi dan Epidemiologi, 1(4).

Sugiyono. (2011). Metode Penelitian Kuantitatif Kualitatif dan $R \& D$. Alfabeta, Bandung.

Sutomo, B., \& Yanti A. D. (2010). Menu Sehat Alami Untuk Batita \& Balita: DeMedia.

Tangga, S. D. S. R. (2015). Susenas 2015. Microdata, Badan Pusat Statistik, Jakarta:

WHO. (2007). Indoor Air Pollution from Solid Fuels and Risk of Low Birth Weight and Stillbirth. Johannesburg, South Africa.

WHO. (2013). The Top 10 Causes of Death: The 10 Leading Causes of Death in the World, 2000 and 2011.

Yisak, H., Gobena, T., \& Mesfin, F. (2015). Prevalence and risk factors for under nutrition among children under five at Haramaya district, Eastern Ethiopia. BMC pediatrics, 15(1), 212. 